\title{
MEDIA AND THE ENVIRONMENT IN MALAYSIA: AN ANALYSIS ON NEWS COVERAGE OF LANDSLIDE DISASTER IN KUALA LUMPUR
}

\author{
JAMILAH AHMAD \\ HABIBAH LATEH \\ UNIVERSITI SAINS MALAYSIA
}

\begin{abstract}
Studies done on media reporting and the environment, particularly on natural disasters area less researched topic in Malaysia. This paper examines the representation of disaster news and analyses on how disaster news reports are being covered in local newspapers by taking a landslide case occurred at Taman Puncak Setiawangsa, Kuala Lumpur in December, 2012. The samples were taken from two local mainstream newspapers as a comparative study. Utusan Malaysia, being the major Malay newspapers in the country targets Malay readers, while The Star, an English-language daily, targets multi-ethnic and middle-class income readers. This study used quantitative and qualitative content analysis in identifying patterns of coverage by both newspapers. The analysis revealed that despite having their own principles, guidelines and ideologies; this study concludes that both newspapers have a lot of similarities in their reporting on this particular disaster. The main similarity is local environmental news is still predominantly presented as straight news.
\end{abstract}

Keywords: Environmental news coverage, Malaysia, landslide, natural disasters, media discourse.

\section{MEDIA DAN ALAM SEKITAR DI MALAYSIA: ANALISIS PELAPORAN BERITA BENCANA TANAH RUNTUH DI KUALA LUMPUR}

\begin{abstract}
Abstrak
Kajian mengenai pelaporan media dan alam sekitar terutamanya yang melibatkan bencana alam masih kurang dilakukan di Malaysia. Oleh itu, artikel ini mengkaji representasi berita mengenai bencana alam dan mengkaji bagaimana berita bencana alam dilaporkan di akhbar tempatan dengan mengambil bencana yang berlaku di Taman Puncak Setiawangsa, Kuala Lumpur pada Disember 2012 sebagai kajian kes. Sampel berita dikumpul dari dua akhbar arus perdana iaitu Utusan Malaysia dan The Star. Akhbar Utusan Malaysia, akhbar harian berbahasa Melayu mensasarkan pembaca dari kalangan orang Melayu manakala akhbar The Star, akhbar harian berbahasa Inggeris lebih mensasarkan golongan pembaca yang terdiri daripada pelbagai etnik dan berpendapatan sederhana. Kajian ini menggunakan kaedah analisis kandungan kuantitatif dan kualitatif dalam mengenal pasti corak pelaporan kedua-dua akhbar. Dapatan kajian menunjukkan, walaupun kedua-dua akhbar mempunyai prinsip, peraturan dan ideologi masingmasing, namun kedua-dua akhbar tersebut mempunyai persamaan yang banyak dari segi
\end{abstract}


pelaporan bencana alam. Persamaan utama dapat dilihat menerusi pelaporan berita mengenai bencana alam yang kebanyakannya dilaporkan dalam bentuk berita langsung.

Kata Kunci: Pelaporan alam sekitar, Malaysia, tanah runtuh, bencana alam, wacana media.

\section{INTRODUCTION}

Malaysia's position is outside the "Pacific Ring of Fire" in terms of geographical location. This means it is in an area free of natural disasters such as hurricanes, tsunamis and the like which often hit neighbouring countries such as Indonesia, Thailand, Cambodia etc. Arguably, most of the disasters that occur in the country are due to human incompetency. Prasana, Lean and Khor (2012:85) stated that Malaysians are anxious of the increasing regularity of the natural disasters and it is disturbing as many of these disasters are caused by the lackadaisical attitude and greed of politicians and policy makers. The public in general are disillusioned as the causes of the problems contributing to such disasters are not put right.

Although Malaysia is not a precipitous country (mountains and hills are less than 25 percent of the terrain), slope failures/landslides are a frequent fact there. Most of the landslides emerge on man-made slopes and this is in essence the upshot of uncertainties related to human factors like insufficiency in design, failing in construction or wretched maintenance (Jamaluddin, 2006 in Qasim, Harahap and Osman, 2013). According to Qasim, Harahap and Osman (2013), about 49 landslides cases out of which 88 percent are recognized with man-made slopes. Along with poor design, incompetency, casualness, raw input data, all these factors contributes towards these frequent occurrences of landslides.

Landslide is a mass wasting, a comprehensive term for any type of down slope movement of earth materials due to several factors such as weather, developmental activities and other reasons. Landslides usually occur at mountainous landscapes and are also common along coastlines and river valleys and may be seen as a conflict between man and nature. Studies have shown that hillside developments can have serious irreversible impacts on the immediate surrounding and downstream environment in the forms of deforestation, soil erosion, water pollution, the extinction of flora and fauna, flash flood and landslides (Habibah and Jamilah, 2011:65). 
Landslide is also a geological phenomenon which includes a wide range of ground movement, such as rock falls, deep failure of slopes and shallow debris flows, which can occur in offshore, coastal and onshore environments. Although the action of gravity is the primary driving force for a landslide to occur, there are other contributing factors affecting the original slope stability. By human exploitation along the hill for various purposes, resulting in soil erosion as well as causing much loss to the residents who live nearby (Habibah and Vijaya, 2012:1).

People staying near the hills are often exposed to the activities of exploration of hills and mountains with a slope greater than 25 degrees and above. This phenomenon becomes more complex when there are more and more of a greedy and irresponsible people baring the hilly areas. Their greed is not only invites disaster to the resident, property and the environment but also cause severe losses to the government. Rapid development along the hillside has been made to meet the current demand. Each development undertaken is not denied, would lead to certain implications. Similarly, the development carried out in the hills would have implications on the environment and also the safety of the residents staying on the hills (Habibah and Vijaya, 2012: 2).

Malaysia was previously shocked by a series of landslides occurrences and other disasters. Most of these tragedies were due to human negligence and not just simply as "an act of God". For example:

1. The landslides that occurred in Bukit Antarabangsa, Ulu Klang in July, 1998 and October, 2000 due to the underground drainage system that is not maintained properly by the developer.

2. Jetty of Pengkalan Sultan Abdul Hamid, Butterworth collapsed on July, 1988 shocked the country because it is the busiest piers in the country. This incident resulted in 32 people dead and 1,674 others injured.

3. On December, 1993, one of the three blocks of condominiums in Highland Towers, Hulu Klang, Selangor collapsed and killed 48 people. The incident occurred after a landslide at the back of the condominium.

4. On November, 2002, a bungalow in Taman Hillview, Ulu Klang owned by former Army Commander, Gen (Rtd) Tan Sri Ismail Omar collapsed after being hit by landslides from the hills next to his house. In the incident, his wife Puan Sri 
Azizah Abdul Aziz and his son Hijaz, two in-laws and two grandchildren and an Indonesian maid died.

5. On May, 2011 - 16 people mostly 15 children and a caretaker of an orphanage were killed in a landslide caused by heavy rains at the Children's Hidayah Madrasah Al-Taqwa orphanage in FELCRA Semungkis, Hulu Langat, Selangor.

6. On December, 2012, 88 residents of bungalows, shop houses and double-storey terrace houses in the Puncak Setiawangsa, Kuala Lumpur were ordered to move out because of soil movement but no casualties were reported.

Recent frequent occurrence of disasters has had great physical and psychological consequences to the victims. Disasters either natural or man-made devastate the lives of individual and communities, stunt economic development and undermine the socio-political stability of a country (Fauziah et al., 2011). Media have been known to play an important role in disseminating information to the public and people often times regard the media as the primary source of information. Community certainly expects the media as the main avenue of information to find out what's going on around them, including disasters occurring around them.

Thus, this article presents a case study and methodology for an environmental comparative analysis specifically on a landslide case that occurred in Taman Puncak Setiawangsa, on last December, 2012.This study also establishes the theoretical framework on which the analysis of the data will be based. The analysis of data consists of reviewing articles and essays from two Malaysian mainstream newspapers with different languages that identify the issue and themes covered by the media. In the end, a conclusion is drawn to develop an understanding of the patterns of news coverage between the two different newspapers on the issue of landslide.

\section{THE ROLE OF THE MEDIA IN COVERING DISASTERS}

The media plays a crucial role in gathering and providing information about disasters to the general public, government officials, relief organizations and environmental groups. The media facilitates discussion about the cause of such disasters, the authorities' preparedness to respond in the wake of such occurrences. Thus, media plays the role of commentator, interpreter and 
gatekeeper as well as also known as the primary source of information that the audience rely heavily on (Prasana, Lean and Khor, 2012; Selo et al., 2015).

According to Schramm (1964), mass media alone or together with other institutions can perform a number of roles as follows:

i. As a speedy provider of information and regularly on time as expected by society.

ii. As a decision maker in consultation with the groups that will clarify the problem being discussed.

iii. As an educator who can provide guidance so that people can think and help in the development and advancement.

According to the National Research Council's Committee on Disasters and the Mass Media, the media can play some roles for public learning about the nature and possible consequences of hazards, such as: preparing the public to meet emergencies; providing mitigation, coping information and warning; providing reassurance and a mood for grieving or assuaging guilt in the aftermath of a tragedy; providing mobilizing information; assessing the post disaster period and the lessons that have been learned; providing a record of activities related to the natural hazard (Wilkins, 1986).

Seo et al. (2011:4) stated that media coverage of disasters involves not just stories of sorrow and misfortune but also stories of survivorship and courage and the media can facilitate positive behaviours by audience members. Media coverage can also promote rescue and recovery efforts by soliciting charitable actions from audience members. Moreover, media can also increase public awareness and provide guidelines for how people can assist in their local communities. More broadly, media has the capacity to enhance public discourses of compassion, which can potentially influence individuals' willingness to help others affected by the disaster.

People feel threatened by all kinds of invisible risks that exist only in terms of knowledge, which means that all depends on the social construction of that risk. In that respect, the social definition of a specific risk can be manipulated, amplified, magnified, or minimized. Especially when key events happened, launch new risk issues and uncertainty reigns, the public has to rely on the messages communicated to them by the media (Vasterman, Yzermans and Dirkzwager, 2005:107). The media can operate in different modes: media can follow, but they 
can also lead. They can report ongoing events, disseminating (official) information to the public. But they can also play a leading role in the social construction of the problem after a disaster, for instance, by creating a news wave based on magnification of one specific perspective. Operating in this mode, the media can have a huge impact on the way that a disaster and the risk issues involve are defined and perceived by the public as well as the authorities (Vasterman, Yzermans and Dirkzwager, 2005:110).

As the media constitutes an important source of the public's information about hazards and disasters, through previous studies it was found that television news and newspaper stories represent two of the most salient mass media outlets concerning information on hazards and disasters (Spencer et al., 1992). Previous research has shown newspapers to be a primary source of public information about environmental issues (McCallum, Hammond \& Covello, 1991; Wakefield and Elliott, 2003). The high dependence on media source shows that the community views environmental issues as external - they are observers, not participants in environmental issues.

\section{THE MALAYSIAN MEDIA AND ENVIRONMENTAL ISSUES - AN OVERVIEW}

In many developing countries, the role of media is shaped to fulfill local needs. In Malaysia, the role of media is shaped not only to disseminate information and as educators as envisaged in the government's policy, but also as a guide to walk hand-in-hand with the government's aspiration and policy in order to survive in the media industry (Fauziah et al., 2011).

In the Malaysian context, the ruling government sees the importance and influence that is often played by the media especially the newspapers that has the power to disseminate information on issues important to the public. The media often serves as a platform for readers to share their ideas and opinions (Mus Chairil et al., 2011). Besides that, according to Jamilah, Gowri \& Nur Nasliza Arina (2015), the media over the years has acquired a reputation for being able to influence the thoughts and actions of public, thus serving as a tool in promoting ideas related to various issues including environmental issues in Malaysia.

It is a truism that the mass media, like any other social institution, do not operate in a social vacuum. There are forces in society that interact with the media, each trying to gain access 
to the media in the hope of exercising influence and control. This often involves the state, political parties, corporate entities, lobby groups, and civil society groups, among others (Mustafa, 2005:25).

The ownership of the mainstream media in Malaysia is generally dominated by the political elites of the stakeholders in turn leads to control over the information presented. Almost all of the mainstream media are controlled by the ruling political parties. Control over the media through ownership either directly or indirectly by the government and the existence of gatekeepers, which monitors trends in news production are among the factors that provide the impetus to the development of blogs and independent news portal in Malaysia (Nur Azween and Nidzam, 2008).

In Malaysia, a newspaper ownership cannot be separated from the political and business people who are normally affiliated with political leaders and groups. This close symbiotic relationship directly impacts the freedom of the press and how the press sets its policies, agenda and how the newspaper frames a certain news issue (Jeniri, 2005).

The current ownership situation could affect environmental coverage in two ways: (i) by eliminating environmental stories in favour of other sensational stories in order to increase circulation and profits as required by the newspaper owners and; (ii) by reporting at a surface level, or not reporting at all on environmental issues which are related to government projects needed for the harmony of multi-ethnic interaction (Nik Norma, 2007:5).

According to Adnan and Kamaliah (2006), in a confined environment such as the media in Malaysia, whatever view that is not aligned with the views of the government, on any issues, including controversial environmental issues will not get much place and space in the media. In other words, people who want to join in the debate over the issues will not get access in the mainstream media. To curb unwelcome critiques of the status quo, media are impelled to practice self-censorship through the inherent threat and enforcement of a wide range of restrictive laws (Smeltzer, 2008; Mustafa, 2005).

Not surprisingly, mainstream Malaysian media are reticent to allow their journalists to critically report on the government's policy and strategy from an environmental point of view (nor, for that matter, from human rights, ethical or critical economic perspectives). Instead, the 
media engage in pro-government reporting that has helped frame environmental issues as an obvious next step for Malaysia’s overall progress and development (Smeltzer, 2008).

As mentioned above, studies on environmental issues particularly on disasters are still less in Malaysia but some of the local researchers did some research on media coverage of environmental issues. Based on previous studies on environmental news in Malaysia, Faridah (2009) found that there are not many news covered on the environment issues in spite of the fact that it is considered important. Based on interviews with two gatekeepers from the two newspapers, it was found that environmental news actually form parts of developmental news covered by the newspapers.

Previous studies also showed that the English language newspaper tend to cover more environmental news compared to the Malay newspaper (Faridah, 2009; Mariah, Raihanah and Md. Salleh, 2004). However, both of the newspapers are said to practice bland reporting on environmental issues. Mariah, Raihanah and Md. Salleh (2004) also stated that English language newspaper tend to be more critical in terms of reporting on environmental issues and trying to educate the public to preserve the environment.

Prasad et al. (2010) also did a research on how the environmental issues are being covered in local Malaysian television channels in their prime-time news broadcast. The news broadcast samples were taken from local television channels TVI and TV3 in Malaysia. They found out that both the channels report promptly and continuously on the disaster incident of 'Bukit Antarabangsa' landslide tragedy, which demonstrated their responsibility as a public broadcaster. Their reports also commanded public attention and tried to invoke actions. Similarly, the news reports provided space for public sphere, where the public citizens and the authorities from government agencies interacted with each other.

\section{SIGNIFICANCE OF THE STUDY}

In Malaysia, major environmental issues that have been covered over the years by the mass media are issues of haze, deforestation and illegal logging which are the major cause of flash floods, soil erosion and landslides, illegal dumping of toxic chemicals, water pollution and management of radioactive wastes (Faridah, 2009). 
Yet studies on environmental issues particularly on disasters are still less in Malaysia because most of the local researchers are more interested on issues related to politics and elections. According to Mariah, Raihanah and Md. Salleh (2004), not much work has been done on the issue of disasters in the media even though it is one of the important issues affecting the lives of people in this country.

Thus, it is vital to study the role of local media in informing their audiences of impending disasters occurring either within the country or overseas and to assess the level of acceptance of information distributed by local media on issues and news related to the development of the disasters (Fauziah et al., 2011).

The review of various studies on environmental news reporting indicated the importance of studying environment news and narrative and techniques in presenting the environmental news. News reporting of environment plays a key role in safeguarding the environmental interests in Malaysia and thus a study of this kind is important in the context of Malaysia (Prasad et al., 2010:3). Therefore, this study works to identify and make comparisons between the patterns in environmental reporting by the two mainstream newspapers in Malaysia, Utusan Malaysia and The Star.

\section{METHODOLOGY}

A content analysis method, both quantitative and qualitative were used to explore how two Malaysian mainstream newspapers cover the disaster specifically a landslide that occurred in Taman Puncak Setiawangsa, last December, 2012. The newspapers namely Utusan Malaysia (UM) and The Star (TS) were selected.

On December 28th, 2012, a landslide was reported in Taman Puncak Setiawangsa, Kuala Lumpur at about $10 \mathrm{pm}$. Most part of the 43 meters concrete barrier in the area collapsed and buried and it is the only access road from Taman Puncak Setiawangsa. 88 families were advised to evacuate their houses and shop lots and it was the first landslide in Setiawangsa since the 1987.

The sample of this study was drawn from December 29th, 2012 to February 22nd, 2013, which represents the peak period of the issue. This study chose the census sample because 
scholars say a census often makes the most sense for research that examines a particular event or series of events (Riffe, Lacy \& Fico, 2005).

The unit of analysis was the article, which included news, editorials, columns, opinions, and letters. The articles were pulled from the respective newspaper's online archives by using "landslide" and "Taman Puncak Setiawangsa" as the keywords. This study tries to analyze the issue according to the following research questions:

a. How do the newspapers portray the issue of landslide in their coverage?

b. What are the differences between both newspapers in reporting on the issue of landslide?

c. What are the themes that have been discussed with regard to the issue of landslide?

\section{RESULTS AND DISCUSSION}

\section{News Frequency}

A total of 65 news articles were collected and analyzed from the two newspapers from 29th December, 2012 to 22nd February, 2013. As the Table 1 shows, of the 65 news articles, The Star published 38 (58.5 percent) news articles and Utusan Malaysia published 27 (67.7 percent) news articles on the issue.

From these findings, we can see that The Star published more news articles on this landslide issue compared to Utusan Malaysia but not by a relatively large amount. This finding demonstrates that The Star allocated a greater priority on this issue than Utusan Malaysia.

Table 1 Frequency of news stories in Utusan Malaysia and The Star

\begin{tabular}{|l|c|c|}
\hline & Frequency & Total (Percent) \\
\hline The Star & 38 & 58.5 \\
Utusan Malaysia & 27 & 41.5 \\
Total & 65 & 100.0 \\
\hline
\end{tabular}




\section{Presence of Pictures}

Photos can produce an array of different interpretations by readers and is an important part of the modern newspaper. Photos can replace many words and express news concisely. Photos can also express any given situation in an accurate, clear and simple manner, plus providing a more interesting pattern to the press as well as making it easier to read. It is undeniable that photos are an important element in the design of a newspaper. Using images is very important in a news report as it not only strengthens the news report but also highlights the facts in the news report which attracts the interest of the readers (Vilashini et al., 2010: 65).

By referring to Table 2 below, it can be concluded that Utusan Malaysia published more photos in the coverage of this landslide issue with 9 news articles or 33.3 percent of the overall news articles with picture inclusions. In contrast, The Star published 11 news articles or 28.9 percent from the total number of news articles published by the newspaper.

Table 2 Presence of photos in news articles of Utusan Malaysia and The Star

\begin{tabular}{|c|c|c|c|c|}
\hline & & The Star & Utusan Malaysia & Total \\
\hline \multirow{2}{*}{ N/A } & Count & 27 & 18 & 45 \\
\hline & Percent & 71.1 & 66.7 & 69.2 \\
\hline \multirow{2}{*}{ Shown } & Count & 11 & 9 & 20 \\
\hline & Percent & 28.9 & 33.3 & 30.8 \\
\hline \multirow{2}{*}{ Total } & Count & 38 & 27 & 65 \\
\hline & Percent & 100.0 & 100.0 & 100.0 \\
\hline
\end{tabular}

\section{Types of stories}

Table 3 shows that straight news reporting predominate the type of articles in both the newspapers. Utusan Malaysia did publish a feature story as The Star did not publish any other articles than straight news. According to Van Dijk (1988), when straight news dominates the coverage, it leaves little room for the creativeness of journalists, resulting in a top-down communication format. Vera (cited in Loo and Mustafa, 2010) argued that Malaysian journalists in general have always been told how to report - just get the official statement and the facts, no need to comment and the feature stories would have to be sober. 
Table 3 Types of stories published in Utusan Malaysia and The Star

\begin{tabular}{|cc|c|c|c|}
\hline & & The Star & $\begin{array}{c}\text { Utusan } \\
\text { Malaysia }\end{array}$ & Total \\
\hline \multirow{2}{*}{ Straight news } & Count & 38 & 26 & 64 \\
& Percent & 100.0 & 96.3 & 98.5 \\
\multirow{2}{*}{ Feature } & Count & 0 & 1 & 1 \\
& Percent & 0.0 & 3.7 & 1.5 \\
\hline \multirow{2}{*}{ Total } & Count & 38 & 27 & 65 \\
& Percent & 100.0 & 100.0 & 100.0 \\
\hline
\end{tabular}

\section{News Sources}

Yang and Md Sidin (2012) stated that sources play an important role in determining the reporting and further development of a news story. It reflects the direction in terms of development and bias of a newspaper and there will be no news if there are no news sources. Table 4 below describes the different types of sources used by both newspapers.

Table 4 Difference of news source used in Utusan Malaysia and The Star

\begin{tabular}{|ll|c|c|c|}
\hline & & The Star & Utusan Malaysia & Total \\
\hline Local government & Count & 12 & 10 & 22 \\
servants & Percent & 31.6 & 37.0 & 33.8 \\
& Count & 2 & 3 & 5 \\
Experts & Percent & 5.3 & 11.1 & 7.7 \\
Professionals/NGOs & Count & 6 & 5 & 11 \\
& Percent & 15.8 & 18.5 & 16.9 \\
Residents/victims & Count & 14 & 4 & 18 \\
Journalists' & Percent & 36.8 & 14.8 & 27.7 \\
observation/opinion & Count & 2 & 0 & 2 \\
& Percent & 5.3 & 0.0 & 3.1 \\
Ministers & Count & 2 & 5 & 7 \\
& Percent & 5.3 & 18.5 & 10.8 \\
\hline \multirow{2}{*}{ Total } & Count & 38 & 27 & 65 \\
& Percent & 100.0 & 100.0 & 100.0 \\
\hline
\end{tabular}


From the above table, we can see that there is no significant difference in the type of news sources used by both Utusan Malaysia and The Star. The table indicates that local government servants were the dominant choices and both newspapers also turned to professionals/NGOs and experts whenever the situations warrant their expertise on the causes of the landslides. Both newspapers also rely on ministers to announce some new policies regarding preventive measures on landslides. Moreover, The Star included voices of the residents/victims at large and it shows that the newspaper tried to include elements of humanity in its reporting.

\section{Orientation of writing}

In terms of orientation of the writings, the table below shows that both newspapers focused more on normal reporting without any other element. Both newspapers did publish but very little news that is critical and educational about landslides and the importance of conserving the environment. As mentioned above, mainstream Malaysian media are reticent to allow their journalists to critically report on the government's policy and strategy from an environmental point of view (nor, for that matter, from human rights, ethical or critical economic perspectives). Instead, the media engage in pro-government reporting (Smeltzer, 2008).

Table 5 Orientation of writing in Utusan Malaysia and The Star

\begin{tabular}{|ll|c|c|c|}
\hline & & The Star & $\begin{array}{c}\text { Utusan } \\
\text { Malaysia }\end{array}$ & Total \\
\hline Normal reporting & Count & 32 & 23 & 55 \\
& Percent & 84.2 & 85.2 & 84.6 \\
Criticism & Count & 3 & 3 & 6 \\
& Percent & 7.9 & 11.1 & 9.2 \\
Educational & Count & 3 & 1 & 4 \\
messages/awareness & Percent & & & 6.2 \\
& & 7.9 & 3.7 & 65 \\
\hline \multirow{2}{*}{ Total } & Count & 38 & 27 & 100.0 \\
\hline
\end{tabular}




\section{News origin}

Table 6 indicates that generally, both newspapers had their own newspaper reporters to cover local events and issues and occasionally they relied on the local news agency's copy that is Bernama (The Malaysian National News Agency). From the above table, it can be concluded that both newspapers did not rely heavily on Bernama in terms of reporting on this particular disaster as they have their own reporters to cover the event.

Table 6 News origin of landslide stories in The Star and Utusan Malaysia

\begin{tabular}{|cl|c|c|c|}
\hline & & The Star & $\begin{array}{c}\text { Utusan } \\
\text { Malaysia }\end{array}$ & Total \\
\hline \multirow{2}{*}{ Newspaper staffs } & Count & 34 & 21 & 55 \\
& Percent & 89.5 & 77.8 & 84.6 \\
& Count & 4 & 6 & 10 \\
\multirow{2}{*}{ Bernama } & Percent & 10.5 & 22.2 & 15.4 \\
& & 38 & 27 & 65 \\
\multirow{2}{*}{ Total } & Count & 100.0 & 100.0 & 100.0 \\
\hline
\end{tabular}

\section{Themes}

In this category, the most important element is the content of the news. The news content will be given specific themes. In the content analysis method, this kind of technique is called thematic analysis; it is used as a way to get the themes in a variety of messages. Table 7 below describes the different types of themes used by both newspapers.

Table 7 Types of themes of landslide stories in Utusan Malaysia and The Star

\begin{tabular}{|ll|c|c|c|}
\hline & & The Star & Utusan Malaysia & Total \\
\hline \multirow{2}{*}{ Background events } & Count & 4 & 4 & 8 \\
& Percent & 10.5 & 14.8 & 12.3 \\
Making new policies & Count & 2 & 3 & 5 \\
& Percent & 5.3 & 11.1 & 7.7 \\
\multirow{2}{*}{ Humanity } & Count & 10 & 3 & 13 \\
Responsibility & Percent & 26.3 & 11.1 & 20.0 \\
\end{tabular}




\begin{tabular}{|ll|c|c|c|}
\hline & Percent & 7.9 & 3.7 & 6.2 \\
Causes & Count & 3 & 1 & 4 \\
& Percent & 7.9 & 3.7 & 6.2 \\
Follow up actions & Count & 13 & 13 & 26 \\
& Percent & 34.2 & 48.1 & 40.0 \\
Educational & Count & 3 & 2 & 5 \\
& Percent & 7.9 & 7.4 & 7.7 \\
& within & & & \\
\hline \multirow{2}{*}{ Total } & Count & 38 & 27 & 65 \\
& Per cent & 100.0 & 100.0 & 100.0 \\
\hline
\end{tabular}

Table 7 above shows the themes covered by both of the newspapers. It is evident that "follow up actions" topped the list for both newspapers. "Follow up actions" here refers to the actions taken by the government after the disaster. Here are some examples of the excerpts taken from the newspapers:

The house that is teetering over the edge of the collapsed retaining wall in Bukit Setiawangsa is to be demolished by Monday. Sentul deputy OCPD Supt Othman Abu Bakar said the green light to demolish the house, half of which had collapsed, was given by the developer of the wall, I\&P Sdn Bhd, and Kuala Lumpur City Hall (The Star, December 30th, 2012).

Ahmad Phesal added that an alternative route to bypass the wall would be built as soon as possible to provide safe access for the residents. He added that a special committee would also be set up to update residents on the situation every day at $5 \mathrm{pm}$ and maintain contact with those involved (The Star, December 30th, 2012).

Dewan Bandaraya Kuala Lumpur (DBKL) dan Institut Kerja Raya Malaysia (Ikram) akan menyediakan Peta Bencana bagi membolehkan risiko tanah runtuh di sekitar Lembah Klang dipantau dan diatasi dengan lebih berkesan. Datuk Bandar Kuala Lumpur, Datuk Ahmad Phesal Talib berkata, proses pemetaan itu akan dimulakan pertengahan Januari ini dengan mengambil masa selama enam bulan (Utusan Malaysia, December 31st, 2012).

Translation: Kuala Lumpur City Hall (DBKL) and the Malaysian Public Works Institute (Ikram) will provide a map to enable disaster risk of landslides in the Klang Valley to be monitored and addressed more effectively. Kuala Lumpur mayor, Datuk Ahmad Phesal Talib said mapping process will begin in mid-January and six months to complete it. 
A point that needs to be emphasized here is that The Star brought an emotional angle to the presentation of news by adopting a "humanity" theme fairly a lot. The following excerpts from the newspaper demonstrated the "humanity" theme.

Bukit Setiawangsa resident Siti Mahfudzah Ashahril, who lives outside of the immediate danger zone, said she was still biting her nails. The 34-year-old administration officer said she also feared for her three young children, aged eight, six and six months.

'I'm afraid the whole thing will collapse if it rains. It has been raining very heavily here for the past week, 'she said (The Star, December 30th, 2012).

Workers at a tailoring shop directly opposite the Bukit Setiawangsa landslide were seen frantically trying to save their stock, fearing that the situation would worsen. Pakaian Kesuma employees hurled rolls of cloth and material out of a window from the second storey while others loaded the items into two lorries. A relative of the shop owner, who declined to be named, said they were afraid the hill would collapse (The Star, December 30th, 2012).

Residents affected by the landslide in Bukit Setiawangsa are fretting over the start of the new school term today as many have been evacuated far from their schools. One of the residents, who only wanted to be known as Dr Hassan, said he had moved into his sister-in-law's home in Hulu Langat, almost $40 \mathrm{~km}$ away from his house.

'For the past few days, it was not a problem because the children were still on their school holidays. However, now that they are starting school, we will have to move into a hotel or rent a house nearby, ' he said (The Star, January 2nd, 2012).

\section{CONCLUSION}

In conclusion, this study found that The Star gave greater emphasis and attention to the landslide coverage than Utusan Malaysia. This is illustrated by the number of news published by both newspapers over the period of 8 weeks. Despite having their own principles, guidelines and ideologies; this study concludes that both newspapers have a lot of similarities in their reporting on this particular disaster. The main similarity is local environmental news is still predominantly presented as straight news, as revealed by previous studies (Mariah, Raihanah and Md. Salleh 2004; Hamidah et al., 2012).

In terms of main sources used, both newspapers still rely heavily on government officials as their dominant choices. It is hardly surprising as the ownership of the mainstream media in 
Malaysia is generally dominated by the political elites of the stakeholders, who in turn leads to control over the information presented. Almost all of the mainstream media are controlled by the ruling political parties. As well as reporting on the actions of the government to solve the problem of landslides, a point that should be noted is that The Star portrays numerous elements of humanity in its reporting by using resources from the victims in voicing their problems. On the other hand, Utusan Malaysia is much more focused on measures taken by the government in addressing the landslide problems.

Thus, this study concludes that the mainstream media in Malaysia has a lot of similarities in the coverage of the environment particularly on the landslide incident. Despite having different ideologies and languages, in terms of environmental reporting, both newspapers showed no clear differences in their reporting.

\section{ABOUT THE AUTHORS}

Jamilah Ahmad is a Professor at the School of Communication, Universiti Sains Malaysia and is currently researching on Environmental Communication, Public Relations, Corporate Social Responsibility (CSR), Communication \& Media Studies, e-Learning and New Media Technology. She can be contacted at E-mail: jahmad@usm.my

Habibah Lateh is a Professor at the School of Distance Education, Universiti Sains Malaysia. Dr. Habibah owns vast local and international experience in landslide research covering from site investigations, modeling, monitoring and human aspects on landslide. She has vast field experience in landslides research, soil erosion and slope stabilization study in Malaysia. She can be contacted at E-mail: habibah@usm.my 


\section{REFERENCES}

Adnan, H., \& Kamaliah, S. (2006). Alam sekitar, kontroversi awam dan Teori Artikulasi: Satu analisis kontroversi Projek Hidro Bakun. Penang: Universiti Sains Malaysia.

Faridah, I. (2009). Investigator cum scientist in the news industry: A study of environmental reporting. Journal of Media and Information Warfare, 2, 3-22.

Fauziah, A., Normah, M., Samsudin, A. R., Fuziah, K. H. B., Abdul Latiff, A., \& Jamaluddin, A. (2011). Confronting environmental risk via communication. The Innovation Journal: The Public Sector Innovation Journal, 16(3), 1-13.

Habibah, L., \& Jamilah, A. (2011). Landslide issues in Penang, Malaysia: Students' environmental knowledge, attitude and practice. GEOGRAFIA Online TM Malaysian Journal of Society and Space, 7(4), 65-72.

Habibah, L., \& Vijaya, G. (2012). Residents awareness towards landslide disaster in Penang. International Journal of Scientific \& Engineering Research, 3(4), 1-7.

Hamidah, A. H., Adnan, H., Kamaliah, H. S., \& Haroon, A. (2012). Covering the environment: Treatment of environmental stories in the Malaysian Malay, English and Vernacular Newspapers. In A. H. Hamidah, A. Azman Azwan, H. A. Jamilah \& N. H. Nik Norma (Ed.), Communication and environment: Sustainability and risk (pp. 29-38). Pulau Pinang: Penerbit Universiti Sains Malaysia.

Jamilah, A., Gowri, S., \& Nur Nasliza Arina, M. N. (2015). The Effectiveness of Video and Pamphlets in Influencing Youth on Environmental Education. Jurnal Komunikasi Malaysian Journal of Communication (JK-MJC), 31(1), 281-296.

Jeniri, A. (2005). Agenda Akhbar dan Agenda Politik MCA. Jurnal Pengajian Media Malaysia, $7(1), 101-110$.

Loo, E. G. \& Mustafa, K. A. (2010). Journalism in good faith: Issues and practices in religion reporting. Selangor: Marshall Cavendish (Malaysia) Sdn Bhd.

Mariah, M., Raihanah, K., \& Md. Salleh, H. (2004). Isu alam sekitar di dalam akhbar arus perdana. Jurnal Komunikasi - Malaysian Journal of Communication (JK-MJC), 20, 1737.

McCallum, D.B., Hammond, S.L., \& Covello,V. T. (1991). Communicating about environmental risks: How the public uses and perceives information sources. Health Education Quarterly, 18(3), 349-61. 
Mus Chairil, S., Latifah, A., Zaharah, H., \& Nurul Ilyana, R. (2011). Biotechnology issues in four Malaysian mainstream newspapers. African Journal of Biotechnology, 10(58), 12497-12503.

Mustafa, K. A. (2005). Politics and the Media in Malaysia. Philippine Journal of Third World Studies, 20(1), 25-47.

Nik Norma, N. H. (2007). The representation of environmental news: A comparative study of The Malaysian and New Zealand Press. New Zealand: University of Canterbury.

Nur Azween, Z., \& Nidzam, S. (2008). Media alternatif sebagai agen perluasan ruang bersuara: Kajian Kes Pilihan Raya Umum Ke-12. In H. K. Worran, H. Shireen, M. K. Mat Zin \& R. Abdul Kadir (Eds.), Prosiding Seminar Politik Malaysia. Shah Alam: Pusat Penerbitan Universiti (UPENA).

Prasad, N. V., Muhammad Hatta, M. T., Mohd Zain, D., \& Thomas, J. Y. (2009). Environment News Broadcast in Malaysia: An Analysis of Prime - Time News Coverage in Local Television Channels. A paper prepared for presentation at an international conference on "Development Communication in the Era of Globalization", organized by Global Communication Research Association, Australia in collaboration with School of Media Studies, Loyola College, Chennai, India, 9-11th July, 2009.

Prasana, R. F., Lean, M., \& Khor, Y. L. (2012). News coverage of the Bukit Antarabangsa landslide in Malaysia: A critical discourse analysis of The Star newspaper. In A. H. Hamidah, A. Azman Azwan, H. A. Jamilah \& N. H. Nik Norma (Ed.), Communication and environment: Sustainability and risk (pp. 64-.86). Pulau Pinang: Penerbit Universiti Sains Malaysia.

Qasim, S., Harahap, I. S. H. \& Osman, S. B. S. (2013). Causal Factors of Malaysian Landslides: A Narrative Study. Research Journal of Applied Sciences, Engineering and Technology, 5(7), 2303-2308.

Riffe, D., Lacy, S., \& Fico, F. (2005). Analyzing Media Messages: Using Quantitative Content Analysis in Research. New Jersey: Lawrence Erlbaum Associates.

Schramm, W. (1964). Mass Media and national development: The role of information in development countries. Stanford: Stanford University Press.

Selo, A., Fauziah, A., Maizatul, H. M., \& Ali, S. (2015). Media and audience: News reporting on conflict issues in Malaysia and Indonesia. Jurnal Komunikasi - Malaysian Journal of Communication (JK-MJC), 31(2), 15-32. 
Seo, M., Sun, S., Merolla, A. J., \& Zhang, S. (2011). Willingness to help following the Sichuan Earthquake: Modeling the effects of media involvement, stress, trust, and relational resources. Communication Research, 39(1) 3-25.

Smeltzer, S. (2008). Biotechnology, the environment, and alternative media in Malaysia. Canadian Journal of Communication, 33(1), 5-20.

Spencer, J. W, Seydlitz, R., Laska, S. \& Triche, E. (1992). The different influences of newspaper and television news reports of a natural hazard on response behaviour. Communication Research, 19(3), 299-325.

Van Dijk, T. A. (1988). News Analysis: Case Studies of International and National News in The Press. New Jersey: Lawrence Erlbaum Associates.

Vasterman, P., Yzermans, C. J., \& Dirkzwager, A. J. E. (2005). The Role of the Media and Media Hypes in the Aftermath of Disasters. Epidemiologic Reviews, 27(1), 107-114.

Vilashini, S., Azizah, H., Mohd Yahya, M. A., \& Azliana, A. A. (2010). Liputan berita tentang Indonesia di Malaysia: Analisis kandungan Utusan Malaysia dan Berita Harian. Jurnal Pengajian Media Malaysia, 12(2), 53-67.

Wakefield, S. E. L., \& Elliott, S. J. (2003). Constructing the News: The Role of Local Newspapers in Environmental Risk Communication. The Professional Geographer, $55(2), 216-226$.

Wilkins, L. (1986). Media coverage of the Bhopal Disaster: A cultural myth in the making. International Journal of Mass Emergencies and Disasters, 4(1), 7-33.

Yang, L.F., \& Md Sidin, A. I. (2012). Framing Interethnic Conflict in Malaysia: A Comparative Analysis of Newspaper Coverage on the Hindu Rights Action Force (Hindraf), International Journal of Communication, 6, 166-189. 